\title{
ENVIRONMENTAL ACTION PROGRAMMES OF THE EUROPEAN UNION - PROGRAMMES SUPPORTING THE SUSTAINABLE DEVELOPMENT STRATEGY OF THE EUROPEAN UNION
}

\author{
Elisabeta-Emilia HALMAGHI \\ emmahalmaghi@gmail.com \\ “NICOLAE BĂLCESCU” LAND FORCES ACADEMY, SIBIU, ROMANIA
}

\begin{abstract}
:
Since 1972, at the level of the European Community, as a result of the Stockholm Conference, a series of successive programmes have been adopted, which have established both future legislative proposals and prospects on environmental policy. The programmes were aimed at setting goals that will be achieved in environmental protection field in the European Community. So far, seven such programmes have been established, called Environmental Action Programmes.
\end{abstract}

\section{KEYWORDS:}

Environment, European Union, sustainable development, environmental protection

\section{Introduction}

Since the 70 s of last century, the European Union a series of successive programmes were set which have set future legislative proposals and perspectives on environmental policy. These programmes aim to establish future goals that will be achieved in environmental protection field. So far, seven such programmes have been established, called Environmental Action Programmes. Action programmes are "a combination of medium-term programmes linked through a strategic approach, consisting of a vertical and sectorial approach to ecological problems". (Institutul European din România, 2012; Coșea \& Dunărinţu, 2013)

\section{Environmental Action Programmes} - Steps Preceding the Sustainable Development Strategy

In 1972, following the Stockholm Conference, the European Council adopted the Environmental Action Programme 1 (EAP 1) covering the period from 1972 to 1977 and it assumed that economic 
development, population's welfare and the environment are closely connected.

The main objectives of the Environmental Action Programme 1 are (Coşea \& Dunărinţu, 2013):

- Preventing and reducing environmental degradation;

- Maintenance of ecological balance;

- Rational use of the nonrenewable natural resources;

- The inclusion of the "environment" component in making decisions for the realization of any activity;

- Public awareness on environmental issues: environmental pollution - short, medium and long term causes and effects, effects of environmental degradation etc.;

- Correlation of EU environmental policy objectives with the policies of the Member States.

The second Environmental Action Programme (EAP 2) was carried out from 1978 to 1981 and, it is basically a continuation of the first Environmental Action Programme (EAP 1).

The first two Environmental Action Programmes focus on water and air: drinking water quality, water protection, waste prevention of water, air quality and protection.

Following the environmental issues addressed in the two environmental action programmes, minimum standards for environmental pollution factors are set and "ideas related to the term of sustainable development are approached" (Coşea \& Dunărinţu, 2013) which would appear in 1987.

The third Environmental Action Programme (EAP 3) was carried out from 1982 to 1986 and the main focus of its concerns was the Internal Market and how it was "influenced by environmental policies through the risks and benefits that accrue to them". (Coşea \& Dunărinţu, 2013)

Under this programme:

- The Strategy of Environmental Protection and Natural Resources is defined;

- Limits on emissions sources are proposed and standards are developed;

- Regulations to avoid non-tariff barriers are established.

- Economic benefits arising from adopted environmental policies are assessed.

Among the objectives of the Environmental Action Programme 3 we mention (Coşea \& Dunărinţu, 2013):

- Efficient use of non- and renewable natural resources;

- Implementation of integrated technologies for environmental protection;

- Emissions' reduction;

- Developing policies on environmental factors' quality;

- Introducing environmental risk management for industry.

Due to economic crises of 1975-1978 and 1981-1983 periods, action programmes have encountered difficulties during implementation (Institutul European din România, 2012).

In the period 1986-1992, the Fourth Environmental Action Programme (EAP 4) was carried out, which aimed mainly at the "Internal Market harmonization with the objectives of environmental protection, aiming to incorporate environmental objectives within the Single European Act" (Coşea \& Dunărinţu, 2013). The actual transition to the integration of the green component in the European policies and introducing the phrase "sustainable development" was made, that would become a tool for improving environmental and life quality and increasing competitiveness.

To reduce wastage, financial instruments such as taxes, subsidies and tradable emission permits have been introduced.

Since the Environmental Action Programme 5 (EAP 5) developed in 19921999, the programmes will receive names. This programme will be called Towards Sustainability and will consider the concept of "sustainable development" as a strategy for environmental policy. It is intended "to imprint a pattern of growth and development that promotes environmental protection and mitigating negative effects of this boom" (Coşea \& Dunărinţu, 2013). 
The programme was developed starting from the fact that, although a series of policies and measures for solving environmental problems were adopted, its quality continued to depreciate. This makes it that the long-term approach is promoted when setting goals.

The Environmental Action Programme 5 supports two major principles (Coşea \& Dunărinţu, 2013):

1. Integrating the environment into all major policy areas, particularly in those policies that cause environmental degradation;

2. Replacing the "command-control" approach, where responsibility is distributed to the different actors: industry, governments, citizens.

Key areas of action covered by this programme are:

- Consideration of sustainable development as "development that allows meeting the needs of current generations without jeopardizing the ability of future generations to satisfy their own needs" (www.worldbank.org);

- Maintaining the quality of life;

- Maintaining continuous access to natural resources;

- Avoiding irreversible damage to the environment.

3. Environmental Action Programmes as Ways to Implement the Sustainable Development Strategy

Until Environmental Action Programme 5 all previous programmes were based solely on legislative instruments. Since that programme, in order to obtain results in all sectors, a mix of tools was grouped, as follows:

a) legislative instruments - are designed to provide and establish fundamental levels within health and environmental protection and to implement global agreements to ensure rules and standards for maintaining the integrity of the Internal Market;

b) economic instruments - for producers and consumers shifting behaviour towards sustainable consumption; c) horizontal tools - education, research, objective information to consumers both to avoid wastage, pollution and for solving environmental problems through actions at the micro level: recovery, reconditioning, reuse, recycle;

d) Financial instruments - Structural Funds, LIFE programmes, the Cohesion Fund, which aim to assist Member States in implementing environmental policies.

The Sixth Environment Action Programme ( $\left.6^{\text {th }} E A P\right)$, also called Our choice, our future was conducted in 2002-2012 and outlined the action framework for environmental policy until 2012. The programme had as a starting point that some environmental problems, such as climate change, biodiversity degradation or over-consumption of renewable and nonrenewable resources, require a much broader approach, not only from a legal standpoint.

Unlike the Environmental Action Programme 5, this programme has been more reticent in setting goals and identifying the tools needed to fight the continuing degradation of the environment. The programme has formulated a framework of objectives and general principles that "will be found more in the thematic strategies on key issues, such as pesticides, natural resources, recycling, soil, urban, marine environment, air”. (Coşea \& Dunărinţu, 2013)

Environmental Action Programme 6 identified four priority areas:

a. Climate change;

b. The nature and biodiversity;

c. The environment, health and quality of life;

d. Natural resources and waste.

For each domain targets and measures to help the establishment of environmental policies and to complement and strengthen existing legislation were established, so as to encompass all important areas.

The Environment Action Programme 7 (EAP 7), called Living well within the limits of our planet, running from 2013-2020. Through this programme, the European Union has "agreed to make greater efforts to protect our natural capital, stimulate 
growth and innovation characterized by resource efficiency and low-carbon and protect the health and welfare of humans within the planet's natural limits". (European Commission, 2013)

Three priority areas where action is needed were identified in the Environmental Action Programme 7:

a) human capital;

b) efficient use of renewable and non-renewable natural resources used in the European Union economies and pollutant emissions reduction from the same economies;

c) the risks that health and peoples' well-being are facing.

Further actions are required for the three priority areas identified, which aim to:

a) protect nature;

b) strengthen ecological resilience;

c) boost economic growth in the European Union in terms of efficient use of renewable and non-renewable natural resources;

d) reduce the amount of emissions of polluting gases;

e) protect the health and welfare of the inhabitants of the European Union against threats from pollution, chemicals and climate change impacts.

The priority objectives of the programme are (Coşea \& Dunărinţu, 2013; European Commission, 2013):

1. protect, conserve and enhance the natural capital of the European Union;

2. EU transition to a green and competitive economy, low-carbon emissions and efficient in terms of resource use;

3. to protect EU citizens from environmental pressures and risks to health and welfare;

4. maximizing the benefits of EU environmental legislation by improving the implementation thereof;

5. develop environmental skills and broadening database policy;

6. ensuring investments for the policy in the field of environment and climate and environmental costs justification of any activities related to society;

7. better integration of environmental considerations into other policy areas and ensuring consistency when formulating new policies;

8. increasing urban sustainability in European Union;

9. EU support to address more effectively the environmental and climate challenges at international level.

Environmental Action Programme 7 does not replace the Sustainable Development Strategy of the European Union, but complements and supports it.

\section{Conclusion}

Environmental Action Programmes set the framework for future action for all areas of environmental policy. These are integrated into horizontal strategies and are taken into account in international environmental negotiations.

\section{REFERENCES}

Coşea, M. \& Dunărinţu, A. (2013). Politici de mediu şi strategii de dezvoltare durabilă in Uniunea Europeană, București: Editura Prouniversitaria.

European Commission. (2013). Living well, within the limits of our planet. $7^{\text {th }}$ EAP The new general Union Environment Action Programme to 2020, available at: http://ec.europa.eu/ environment/pubs/pdf/factsheets/7eap/en.pdf, accessed at 06.08.2016.

Institutul European din România. (2012). Ghidul politicilor Uniunii Europene - Nr. 4. Politica de Mediu, available at: http://www.ier.ro/sites/default/files/pdf/politica de mediu brosura nr.4 .pdf, accessed at 27.07.2016.

http://www.worldbank.org, accessed at 15.07.2016. 